The Digital Object Identifier - DOI: 10.37952/ROI-jbc-01/20-64-12-34

Submitted on December 28, 2020.

\title{
Study of the nutritional value, chemical and biological safety of feeds obtained from agricultural and industrial waste
}

\author{
(C) Oksana V. Shlyamina, ${ }^{{ }^{+}}$Albina A. Samatova, Yulia G. Ataeva, Zilya D. Murtazina, \\ Alsu R. Makaeva, Igor M. Fitsev, and Zhanna R. Nasybullina \\ FSBSI «Federal Center for Toxicological, Radiation and Biological Safety » (FSBSI «FCTRBS-RRVI»). \\ Nauchnyi Gorodok-2. Kazan, 420075. Republic of Tatarstan.Russia. E-mail: mishinanailyan@yandex.ru
}

\begin{abstract}
*Supervising author; ${ }^{+}$Corresponding author
Keywords: stillage, yeast, cake, meal, molasses, biological and chemical safety, feeding of farm animals, physicochemical methods of analysis.
\end{abstract}

Abstract
Waste from agricultural and industrial production is one of the factors of environmental pollution. Together with this, they are a valuable raw material and can be used, for example, for the manufacture of additional animal feed. The article provides information on the rational use of valuable agricultural and industrial waste as additives in the rations of feeding farm animals and poultry.

The health of farm animals and poultry, their productivity depends on the quality and balance of feed. An unbalanced diet leads to metabolic disorders. The data on the chemical composition of molasses, cake and meal, which are used in animal husbandry and poultry farming, as an additional feed with a high protein content, are given. Molasses, which is a by-product of sugar beet production, contains easily digestible carbohydrates, and its use in animal husbandry as an additional feed solves the problem of sugar deficiency.

The Testing Center (IC) of the Federal State Budgetary Scientific Institution "FSBSI «FCTRBSRRVI" conducted research on sunflower cake, rapeseed and sunflower meal in terms of feed value (mass fraction of moisture, mass fraction of crude protein, mass fraction of crude fiber, mass fraction of crude fat). The results of the study of beet molasses samples are presented in terms of quality indicators: mass fraction of dry substances, mass fraction of sugar (by direct polarization), and mass fraction of reducing sugars. The studies carried out indicate that $95 \%$ of cake, meal and beet molasses obtained from agricultural and industrial waste, in terms of feed value, meet the requirements of the current regulatory documentation.

\section{References}

[1] A.R. Makaeva, O.V. Shlyamina, and I.M. Fitsev. Monitoring the nutritional value and chemical safety of the main feeds of the Republic of Tatarstan according to the results of studies carried out in 2019. Butlerov Communications. 2020. Vol.62. No.4. P.123-128. DOI: 10.37952/ROI-jbc-01/20-62-4-123

[2] GOST 80-96 Sunflower cake. Specifications. Moscow: Interstate Council for Standardization, Metrology and Certification. 1996. (russian)

[3] GOST 30257-95 Toasted rapeseed meal. Specifications. Moscow: Interstate Council for Standardization, Metrology and Certification. 1995. (russian)

[4] GOST 11246-96 Sunflower meal. Specifications. Moscow: Interstate Council for Standardization, Metrology and Certification. 1996. (russian)

[5] Secondary material resources of the food industry (education and use). Reference book edited by. A.E. Yurchenko. Moscow: Economy. 1984. [Electronic resourse]. Access mode: http://www.bibliotekar.ru/vtorichnye-resursy/12.htm.

[6] P. Searmsirimongkol, P. Rangsunvigit, M. Leethochawalit, S. Chavadej. Hydrogen production from alcohol distillery waste water containing high potassium and sulfate using an anaerobic sequencing batch reactor. Int. J. Hydrog. Energy. 2011. Vol.36. P.12810-12821.

[7] S.S. Nikulin, M.A. Provotorova, N.S. Nikulina. Used oin the manufacture of emulsion rubber waste of sugar manufacture. Proceedings of the Voronezh State University of Engineering Technologies. 2015. No.2. P.195-198. (russian) 
STUDY OF THE NUTRITIONAL VALUE, CHEMICAL AND BIOLOGICAL SAFETY OF FEEDS OBTAINED..._34-39

[8] N.V. Trofimov. Problems of drying molasses in modern dryers. 2012. [Electronic resourse]. Access mode: http://borona.net/highttechnologies/processing/Problems_of_drying_molassein_modern_dryers.ht ml

[9] Osman A. Osman, Nawal M. Elkhair, Khalid A. Abdoun. Effects of dietary supplementation withdifferent concentration of molasses ongrowth performance, blood metabolitesand rumen fermentation indices of Nubiangoats. BMC Veterinary Research.

[10] F.S. Khaziakhmetov, R.S. Gizatullin, T.A. Faritov, Kh.Kh. Galin, M.V. Sharipov, M.G. Mannapov. Feeding highly productive cows. Ufa: World of Printing. 2008. 60p. (russian)

[11] A.G. Zabrodsky. On self-heating and molasses spoilage. Microbiological industry. 1975. Vol.3. P.1822. (russian)

[12] B.G. Krivovoz. ABSTRACT dissertation for the degree of candidate of technical sciences «Improving the technology of long-term storage of beet molasses with minimal sugar losses». Moscow. 2009. 22p. (russian)

[13] GOST 30561-2017 Sugar beet molasses. Specifications. Moscow: Standardinform. 2017. (russian) 